\title{
Proximate composition of some agricultural wastes in Nigeria and their potential use in activated carbon production
}

\author{
ADEYI, OLADAYO \\ Department of Chemistry and Biochemistry, Bowen University Iwo ,Osun State \\ adeyioladayo350@yahoo.com
}

\begin{abstract}
The proximate composition of five agricultural wastes were determined and latter subjected to low temperature conversion process in the presence of nitrogen atmosphere. These agricultural wastes are Cocos nucifera husk, Theobroma cacao pod, Kola nitida pods and Plantago major peels(ripe and unripe peels). All the samples investigated have different intrinsic proximate compositions which affect the yields of their respective chars. Out of the sample investigated, Cocos nucifera husk recorded the lowest bulk density $\left(0.0746 \mathrm{~g} / \mathrm{cm}^{3}\right), \mathrm{ash}$ content $(3.95 \%)$,cellulose contents $(0.52 \%)$ and has the lowest char yields.On the other hand ,Theobroma cacao pods recorded the highest cellulose content( $41.92 \%)$,ash contents $(12.67 \%)$, crude fiber content $(33.60 \%)$ and has appreciably high char yields. The lignin contents of samples fell in the range of $(6.06 \%-33.60 \%)$. The percentages of chars obtained after conversion at $420^{\circ} \mathrm{C}$ for each of the precursors were relatively lower to those obtained at $360^{\circ} \mathrm{C}$. The percentage yield for all the samples fell within the range of $46-64 \%$ for $360^{\circ} \mathrm{C}$ and $43-58 \%$ for $420^{\circ} \mathrm{C}$. Hence,because of their high carbon yields and their inherent compositions ,they can serve as precursors for activated carbon production. @ JASEM
\end{abstract}

Agricultural wastes are all forms of plant-derived or animal-derived material that are considered useless either because they have no known positive economic importance or because they are not grown/raised for any specific purpose.These include woods, herbaceous plants, crops and forest residues,animal wastes etc.In Nigeria ,large quantities of these wastes are produced anually and are vastly under utilised.Although there are reports on the removal of dye stuffs by saw dust(Poots et al. 1976), hard wood (Asfour et al. 1985),peanut shell(Voudrias et al. 1999). Since agricultural wastes are available abundantly at no or low costs, it has the potential to provide a low cost adsorbent for cleaning our environment.Adsorption onto activated carbon appears to be the most interesting from point of view of large scale application,simple technology and cost effectiveness(Kadirvelu and Namasivayam 2003). These activated carbon (commercial) are usually very costly and readily unavailable and therefore can hardly be afforded in most developing countries like Nigeria due to limited availability of foreign exchange.

Activated carbon is prepared by subjecting a precursor or parent material to either a chemical or thermal process to remove non-carbon atom from the material leading to the development of internal porosity,increased surface porosity,and increased surface area.Precursors of activated carbons are materials of inherent porosity, filtrability and high carbon content. In this study we investigated the proximate composition of some agricultural wastes in other to explore their potential for active carbon production.

\section{EXPERIMENTAL AND METHODOLOGY}

Materials: Dried pods of cocoa,kola, and coconut husk were collected from a farm in Ogo -Olowa Local Government Area of Ogbomoso,Nigeria, while peels of (ripe and unripe ) of plantago major were collected from Takie area of Ogbomoso North Local Government,Oyo State Nigeria

Wet plantago major peels were dried for about 48hours in the sun to ensure that water is removed.The already dried samples of cocoa pods ,coconut husks and kola nuts pods were futher sun dried for 48hours after sand and debris have been removed from them.

Each of the sample materials were ground into smaller sizes by a grinding machine at the wood extraction laboratory,Chemistry Department of University of Ibadan.

Each was latter seived into:

(a) $<2.360-1.000 \mathrm{~mm}$ particle size

(b) $<1.000-0.500 \mathrm{~mm}$ particle size

(c) $<0.500 \mathrm{~mm}$ particle size

using set of standard sieves of corresponding apertures.

The sized samples were stored in polythene bags and labeled prior to analysis and conversion/pyrolysis.

All chemicals used were analar grades and no futher purification were needed.Weight of the sample were taken using $\mathrm{H} 18$ mettler balance of $0.0001 \mathrm{~g}$ accuracy and gallen kamp oven operating at $105^{\circ} \mathrm{C}$ was engaged.

Method: Particle size of $<2.360-1.000 \mathrm{~mm}$ were used for bulk density and moisture content determination while particle size $1.000-0.500 \mathrm{~mm}$ were used for crude fiber content, ash content, hemicellulose, lignin and cellulose fraction determination for better result reproducibility for each of the agricultural waste samples investigated.All the proximate analysis were conducted by the methods of Anderson and Ingram 1979.

Carbonization of the samples which involved subjecting $500 \mathrm{~g}$ of each of the precursors to low temperature conversion process in an innert atmosphere of nitrogen gas was done by the 
method of Adebowale and Bayer ( 2002).Equal mass of the sample was used during the carbonization experiment. The carbonization was carried out at two different temperatures of $360^{\circ} \mathrm{C}$ and $420^{\circ} \mathrm{C}$ in the presence of nitrogen to disallow oxidation of carbon.The conditions of the experiment were that $1 \mathrm{~L} / \mathrm{mins}$ of Nitrogen flow and $9.7 \mathrm{~J} / \mathrm{min}$ of heating rate were used.All experiments were conducted in triplicates, and all the distillates collected,measured and recorded.

The yield was calculated thus:

$\%$ yield $=\frac{M^{*}}{M^{* *}} \times 100$

$\mathrm{M}^{*}=$ Mass of the char

$\mathrm{M}^{* *}=$ Initial mass of the sample

\section{RESULT AND DISCUSSION}

The bulk density and the proximate chemical composition of the samples are presented in table 1.The bulk densities ranged from $0.074 \mathrm{~g} / \mathrm{cm} 3$ to $0.4675 \mathrm{~g} / \mathrm{cm} 3$.The values obtained are in accordance with those reported by Adebowale and Bayer 2002 for agricultural hulls.Unripe plantain peels (plantago major) recorded the highest bulk while coconut husk(cocos nucifera) has the lowest.The cocoa pods (Theobroma cacao),Kola nut pods (cola nitida), and ripe plantain peels recorded $0.3591,0.3233$ and $0.4090 \mathrm{~g} / \mathrm{cm} 3$ respectively.

Table 1 Data for mean bulk density and proximate composition of samples

\begin{tabular}{|c|c|c|c|c|c|c|c|}
\hline $\begin{array}{l}\text { Sample } \\
\text { Type }\end{array}$ & $\begin{array}{l}\text { Bulk } \\
\text { Density } \\
\mathrm{g} / \mathrm{cm} 3\end{array}$ & $\begin{array}{l}\text { Moisture } \\
\text { Content } \%\end{array}$ & $\begin{array}{l}\text { Ash } \\
\text { Content } \%\end{array}$ & $\begin{array}{l}\text { Crude } \\
\text { Fiber } \\
\text { Content } \%\end{array}$ & $\begin{array}{l}\text { Hemi- } \\
\text { Cellulose } \\
\text { Content } \%\end{array}$ & $\begin{array}{l}\text { Lignin } \\
\text { Content } \%\end{array}$ & $\begin{array}{l}\text { Cellulose } \\
\text { Content } \%\end{array}$ \\
\hline $\begin{array}{l}\text { Coconut } \\
\text { Husk }\end{array}$ & \begin{tabular}{l}
\multicolumn{1}{c}{${ }^{\mathrm{a}}$} \\
0.07 \\
\pm 0.00
\end{tabular} & $\begin{array}{l}{ }^{c} \mathrm{a} \\
5.43 \\
\pm 0.08\end{array}$ & $\begin{array}{l}3.95 \\
\pm 0.04\end{array}$ & $\begin{array}{r}\text { a } \\
30.34 \\
\pm 0.74\end{array}$ & $\begin{array}{l}{ }^{c}{ }^{\mathrm{a}} \\
23.70 \\
\pm 0.62\end{array}$ & $\begin{array}{l}{ }^{c} \mathrm{a} \\
3.54 \\
\pm 0.01\end{array}$ & $\begin{array}{l}{ }^{\mathrm{a}} \\
0.52^{2} \\
\pm 0.01\end{array}$ \\
\hline $\begin{array}{l}\text { Cocoa } \\
\text { Pods }\end{array}$ & $\begin{array}{l}{ }^{c} \mathrm{~b} \\
\pm 0.01\end{array}$ & $\begin{array}{l}10.04^{\mathrm{b}} \\
\pm 0.03\end{array}$ & $\begin{array}{r}\quad b \\
12.67 \\
\pm 0.19\end{array}$ & $\begin{array}{r}\quad \mathrm{b} \\
33.60 \\
\pm 0.15\end{array}$ & $\begin{array}{l}35.26 \\
\pm 0.05\end{array}$ & $\begin{array}{l}\quad \mathrm{b} \\
0.95 \\
\pm 0.04\end{array}$ & $\begin{array}{l}41.92 \\
\pm 0.09\end{array}$ \\
\hline $\begin{array}{l}\text { Kola nut } \\
\text { Pods }\end{array}$ & $\begin{array}{l}{ }^{c}{ }^{c} \\
\pm 0.00\end{array}$ & $\begin{array}{l}11.999^{\mathrm{c}} \\
\pm 0.09\end{array}$ & $\begin{array}{l}7.67^{c} \\
\pm 0.11\end{array}$ & $\begin{array}{r}\text { c } \\
26.84 \\
\pm 0.07\end{array}$ & $\begin{array}{l}{ }^{c} \mathrm{c} \\
40.41 \\
\pm 0.11\end{array}$ & $\begin{array}{l}{ }^{c}{ }^{c} \\
21.29 \\
\pm 0.27\end{array}$ & $\begin{array}{l}\quad{ }^{c} \\
38.72 \\
\pm 0.17\end{array}$ \\
\hline $\begin{array}{l}\text { Plantain } \\
\text { Peels } \\
\text { (ripe) }\end{array}$ & $\begin{array}{l}\quad \mathrm{d} \\
0.41 \\
\pm 0.00\end{array}$ & $\begin{array}{l}\quad \text { d } \\
8.71 \\
\pm 0.02\end{array}$ & $\begin{array}{r}\mathrm{b} \\
11.73 \\
\pm 0.61\end{array}$ & $\begin{array}{l}6.06 \\
\pm 0.04\end{array}$ & $\begin{array}{l}15.07{ }^{\mathrm{d}} \\
\pm 0.09\end{array}$ & $\begin{array}{l}1.63 \\
\pm 0.02\end{array}$ & $\begin{array}{l}\quad \mathrm{d} \\
13.87 \\
\pm 0.02\end{array}$ \\
\hline $\begin{array}{l}\text { Plantain } \\
\text { Peels } \\
\text { (unripe) }\end{array}$ & $\begin{array}{l}{ }^{\mathrm{e}} \\
0.48 \\
\pm 0.00\end{array}$ & $\begin{array}{l}8.22 \\
\pm 0.03\end{array}$ & $\begin{array}{l}\quad{ }^{\quad d} \\
9.51 \\
\pm 0.59\end{array}$ & $\begin{array}{l}{ }^{\mathrm{d}} \\
6.24 \\
\pm 0.02\end{array}$ & $\begin{array}{l}11.38 \\
\pm 0.03\end{array}$ & $\begin{array}{l}{ }^{c} \mathrm{~d} \\
1.75 \\
\pm 0.02\end{array}$ & $\begin{array}{l}10.15^{\mathrm{e}} \\
\pm 0.04\end{array}$ \\
\hline G. Mean & 0.33 & 8.88 & 9.10 & 20.61 & 25.16 & 5.83 & 21.04 \\
\hline$\pm \mathrm{SE}$ & 0.05 & 0.72 & 1.04 & 4.00 & 3.74 & 2.59 & 5.46 \\
\hline
\end{tabular}

Table 2 Yield of chars at $360^{\circ} \mathrm{C}$

\begin{tabular}{lcc}
\hline Sample & Volume of distillate $\left(\mathrm{cm}^{3}\right)$ & Yield \% \\
\hline $\begin{array}{l}\text { Coconut } \\
\text { Husk }\end{array}$ & 15 & 45.94 \\
$\begin{array}{l}\text { Cocoa } \\
\text { Pods }\end{array}$ & 22 & 49.99 \\
$\begin{array}{l}\text { Kola nut } \\
\text { Pods }\end{array}$ & 20 & 55.38 \\
$\begin{array}{l}\text { Plantain peels } \\
\text { (ripe) }\end{array}$ & 20 & 53.10 \\
\hline $\begin{array}{l}\text { Plantain peels } \\
\text { (unripe) }\end{array}$ & 6 & 63.10 \\
\hline
\end{tabular}

Table 3 Yield of chars at $420^{\circ} \mathrm{C}$

\begin{tabular}{|c|c|c|}
\hline Sample & Volume of distillate & Yield $\%$ \\
\hline Cocoanut & & \\
\hline Husk & 10 & 43.94 \\
\hline Cocoa & & \\
\hline Pods & 31 & 42.71 \\
\hline Kola nut & & \\
\hline Pods & 23 & 54.70 \\
\hline $\begin{array}{l}\text { Plantain peels } \\
\text { (ripe) }\end{array}$ & 25 & 57.10 \\
\hline $\begin{array}{l}\text { Plantain peels } \\
\text { (unripe) }\end{array}$ & 10 & 47.10 \\
\hline
\end{tabular}

* Corresponding author: Adeyi, Oladayo 
Table 4 Data of percentage yield of chars obtained from carbonization at $360 \mathrm{C}$ and $420 \mathrm{C}$

\begin{tabular}{|c|c|c|}
\hline Sample & Yield at $360^{\circ} \mathrm{C}(\%)$ & Yield at $420^{\circ} \mathrm{C}(\%)$ \\
\hline Coconut & $\mathrm{a}$ & $\mathrm{a}$ \\
\hline Husk & 45.94 & 43.94 \\
\hline Cocoa & $\mathrm{b}$ & $\mathrm{a}$ \\
\hline Pods & 49.99 & 42.71 \\
\hline Kola nut & $\mathrm{c}$ & $\mathrm{b}$ \\
\hline Pods & 55.38 & 54.73 \\
\hline Plantain peels & d & $\mathrm{c}$ \\
\hline (ripe) & 53.10 & 47.10 \\
\hline Plantain peels & $\mathrm{e}$ & $\mathrm{d}$ \\
\hline (unripe) & 63.05 & 57.10 \\
\hline
\end{tabular}

A logical relationship exists between the bulk density of the samples and their corresponding char yields. Table 4 shows the results of char yields at $360^{\circ} \mathrm{C}$ and $420^{\circ} \mathrm{C}$.It was observed that the char yields of the samples tend to increase as the bulk density increases.Kola nut pods and cocoa pods have appreciably high moisture contents of $11.99 \%$ and $10.04 \%$ respectively and hence the high distillate collected during the carbonization process. The results of condensed matter and char yields are as presented in table 2 and table 3 for carbonization at $360^{\circ} \mathrm{C}$ and $420^{\circ} \mathrm{C}$ respectively

The ash contents of the samples ranged from $3.95 \%$ to $12.67 \%$.The values are relatively higher than those reported by Adebowale and Bayer(2002) for agricultural hulls. The ash contents recorded for coconut husk, cocoa pods, kola nut pods, ripe plantain peels and unripe plantain peels are 3.95,12.67,7.67,11.73 and 9.51\% respectively.Coconut husk and cocoa pods however recorded lowest and highest respectively. The samples with higher ash contents are however found to have high yield as in the case of kola nut.The ash contents are the inorganic content of the samples.The results of lignin and cellulose composition of the samples showed logical relationships with the yield of chars. The cellulose composition ranged from $0.52 \%$ to $41.92 \%$ for all the agricultural wastes investigated.Coconut husk has the lowest cellulose composition value of $0.52 \%$ and the lowest char yields at both temperatures. This could be due to low proportion of lignin content (3.54\%) and cellulose contents $(0.52)$.Cocoa pods which have the highest cellulose contents of $41.92 \%$ did not however record the highest char yield as shown in Table 4.The reason might be due to high moisture contents of the sample $(10.04 \%)$ and that the sample contained high proportion of volatile matter, which was observed during carbonization process.

The percentage of lignin in the samples are $3.54,0.95,21.29,1.63$ and $1.75 \%$ for coconut husk ,cacao pods,kola nut pods,ripe plantain peels and unripe plantain peels respectively.

The crude fiber content values were found to be $30.34,33.60,26.54,6.06$, and $6.24 \%$ for coconut

* Corresponding author: Adeyi, Oladayo husk,kolanut pods,ripe plantain peels and unripe plantain peels respectively.Plantain peels recorded appreciably higher yield with unripe plantain the highest.The results of the proximate analysis of the plantain peels showed that it contained high percentage of ash content and relatively high cellulose and hemi cellulose contents

The values of proximate analysis of kola nut pods showed a high percentage of cellulose content $(38.72 \%)$,lignin contents $(21.29 \%)$,hemicellulose content(40.41\%) and crude fibers content $(26.64 \%)$. The char yields of kola nut pods are also very high with $55.38 \%$ at $360^{\circ} \mathrm{C}$ and 54.73 at $420^{\circ} \mathrm{C}$ as shown in table 4. High yields of kola nut pods could be due to high lignocellulose content of the sample.

Coconut husk,however recorded the lowest char yield of $45.94 \%$ at $360^{\circ} \mathrm{C}$ and $43.34 \%$ at $420^{\circ} \mathrm{C}$ among all agricultural wastes investigated.The proximate analysis revealed that coconut husk has the lowest proportion of cellulose content $(0.52 \%)$ and low composition

of lignin content(3.54\%).Lower composition contents of cellulose and lignin could however be responsible for its low char yields.

The result of char yields at $360^{\circ} \mathrm{C}$ and $420^{\circ} \mathrm{C}$ are in table 2 and 3.The results showed a reduction in char yield from $360^{\circ} \mathrm{C}$ to $420^{\circ} \mathrm{C}$. From table 4 , it is revealed that more condensed matter was obtained from charring at $420^{\circ} \mathrm{C}$ which however could account for a reduction in char yields.

Conclusion: Five different sample of agricultural origin were characterized by their proximate analysis and the samples were further charred in an inert nitrogen atmosphere. Cocoa pods has the highest crude fiber contents, its char yields were also vey high, while coconut husk has the lowest bulk density, cellulose contents and correspondingly low char yields. The result of the analyses showed that all the agricultural wastes investigated could serve as precursors for active carbons and the result of proximate analysis showed that the inherent compositions of each agricultural samples greatly affect the yields of their respective chars. 


\section{REFERENCES}

Adebowale, K O ; Bayer, E (2002). Active carbons from low temperature conversion chars.Electronic J. Eviron.Agric. Food Chem.7(11),3304-3315.

Anderson, J M ; Ingram, J S (1979). TSBF Handbook of Methods.CAB,UK.

Asfour, H.M . Fadali, O . Nassar M M ;El-Geundi M.S(1985). Equilibrium studies on adsorption of basic dyes on hard wood. J. Chem. Technol.Biotechnol.35A,21-27.
Kadirvelu, K.; Namasivayam, C (2003). Activated carbon from coconut coir pith as metal adsorbent:adsorption of $\mathrm{Cd}(\mathrm{II})$ from aqeous solution.Adv.Environ.Res.1,471-478.

Poots, V.J.P. McKay, G ; Healy J. J (1976). The removal of acid dye from effluent using natural adsorbents II:Wood.Wat.Res. 10,10671070 .

Voudrias, E . Fytanos, K ; Rozani E (2002). Sorption-Desorption Isotherms of Dyes from aqeous solutions and waste water with different sorbent materials.Int. J. Chem. 4,7583 . 